used for binding Gøvernment documents, I expressed doubts as to the buckram approved, kn॰wn as No. 666, being insect-prøof; and this opinion has since been con-
firmed by experiments made by the Philippine Bureau of Science, Dr. Stratton and myself.

My $\bullet$ wn experiments with a poison of an entirely different character gave -f the various kinds of binding materials tested was treated with my preparation and the other half left untouched. They were placed in boxes and exposed to the attacks of the roaches for various periods. Upøn examination, I found that while the coloring matter in certain samples had been eaten $\bullet$ both the treated and untreated portions, the poisoned portions of quite a number of the color although of different manufacture as regards to on sample, were eaten and the ther piece was left undis-

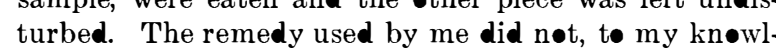
edge, kill any of the insects. Frøm a comparisøn of the results, I arrived at the conclusion that the material used for cøating the buckrams, etc., in a number of cases, had neutralized the effective action of the preparation used by me, and that in order tø really $\bullet b$ tain a material that would be insect-proof, it would be necessary to use such coloring matters as

The fact that insects seem to show preference for certain colors used in binding materials, has already been noticed by a few of my correspondents; and alsø by myself while making researches in Florida last summer.

The Philippine Bureau of Science, finding that the buckram used as a standard was not insect-proof in the Islands, made another series of experiments, and have produced material which they claim is absolutely safe I have made request for same, I am unable t• pass judgment upon it.

Althøugh scientists have been experimenting up॰n binding materials in order t• •btain •ne that would be exemp from the ravages of these little insects. little has been done toward preserving the most important part, and which, according to my investigations, receives the greatest injury, namely, the printed portion of the book. Some experiments made by.J. Rodway, Es .. Secretary of the Royal Agricultural and Commercial Søciety of British per, turpentine, kerøsene and corrosive sublimate, failed to stop the borings of the insects. I have sent bøards and
bøoks made of different papers which I have treated with bøoks made of different papers which I have treated with world, and the results as to the effectiveness of the remedy used should be received during the coming winter.

Arsenic in its various forms is used in large quantitie in the materials used in book-making, though denied by in the materials used in book-making, though denied by show the presence of this substance, which is of use to the show the presence of this substance, which is of use to the
insects. The elimination of arsenic in materials used in bøok-making would not $\bullet$ nly do away with a søurce of attraction to the insects, but save people from being pøisøned, as anyøne familiar with the literature of pøisøns kn॰ws.

Books Disease Carriers.-Again, I speak upøn the transmission of diseases by bøoks, because the greatest disease carrier amøng insects that we kn॰w of to-day is

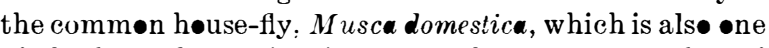
of the book-destrøying insects. There are a number of instances where the maggots of the fly have been found living upøn paper, kept in damp places, but the damage done directly to the bøok is as nothing when compared t• the damage done by their transferring germs, and, unless means are taken for their extermination, they will rank

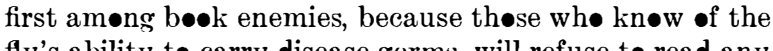

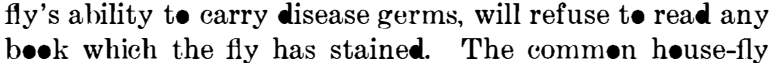
bøok which the fly has stained. The common house-fly
is $\bullet$ nly found around the habitation of man, showing that is $\bullet$ nly found arøund the habitation of man, shøwing that
it has evolved frøm søme other form which formerly lived in the $\bullet$ pen until it has nøw becøme thorøughly domesticated, as other forms have done, are doing, and will do i the future.

According to Dr. Howard, a single female fly in the spring might, therefore, become the progenitor of 195 , $312,500,000,000,000$ flies by the end of the summer or mid-autumn, and alløwing one million flies to a bushel makes •ver 193 million bushels, each one of whom i capable of spreading contagion. An investigation made at the Agricultural Experiment Station at Storrs, Connecticut, in 1908, up॰n 414 flies, shøwed that the number of bacteria $\bullet$ a single fly may range all the way fr $\bullet 550$ t• $6,600,000$, an average of $\bullet$ ne and one-fourth millions bacteria on each, an almost incredible number to be found $\bullet$ n such a small $\bullet$ bject. The $\bullet$ bjectionable class,

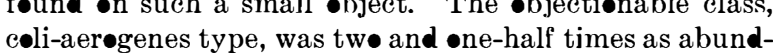

ant as the favorable acid type. Now this only includes thøse $\bullet$ the $\bullet$ utside, and every bacteriøløgist kn॰ws that arge numbers are found in the intestines and expelled with the excreta. Mr. N. A. Cøbb, in his article "The House-Fly," ${ }^{3}$ states that a well-fed fly defecates 104 times in less than tw॰ hours, and that spores were found in fiftyfive of the specks. These specks, containing germs, are

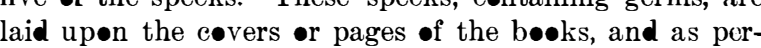
sonal ebservation shows that a very large portion of readers moisten their fingers in turning •ver the leave of a bøok, it is readily seen how the fly speck upøn the paper is moistened, adheres to the finger and the germ transplanted to the mouth, where they at once find th proper conditions and proceed to breed, resulting in the which it is impossible t $\bullet$ trace, on account of the slight consideration given by the medical world at the present

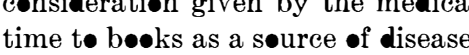

The danger of contracting disease by the fingers damp-

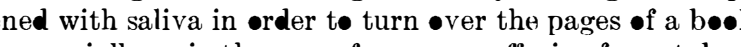
is especially sø in the case of persøns suffering frøm tubereulosis, whc se sputum contains millions of the bacilli. The saliva drying, the Tubercls bacilli cling to the fiber of the pacer, and as søon as an七ther persøn, who also has the vulgar habit of wetting the fingers in turning the pages, uses the bøok, the germs are remøved to fertile søil. Many ther diseases, especially skin diseases, are withøut doubt requently transmitted by this means.

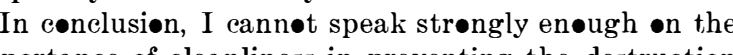
mportance of cleanliness in preventing the destruction -f bøoks by insects, and the spreading of disease. 'Th volumes in the library should be kept thorøughly cleaned, the attendants $\bullet$ ught t $\bullet$ clean their hands frequently, and the patrons compelled to wash their hands before using fingers in turning pages. These precautions will halp to decrease the spread of tuberculosis and other diseases, and do away with the grease stains $\bullet$ n the paper, which are breeding grounds for germs and attractive feeding places for insects. Screens should be placed on all windows and doors to prevent the entrance of flies, and by these means only will the destruction of the stores of accumulated come.

National Geographic Magazine, vol. xxi..,1910, pp. 371-380.

\title{
Human Evidence of Evolution
}

\section{Is Natural Selection Dependent on Small Variations or on Large Mutations?}

\section{By A. M. Gossage, M.D.}

TuE problems of heredity are attracting a gratifying amount of attention from many classes - the general public, the professed biologist, the mathematician, and, of late, the medical profession. Naturally it is the inheritance of human qualities which excites the greatest interest; and there is always a desire to extend to the human race any conclusions founded on the study of animals or plants. It has been claimed by Archdall Reid that the study of human beings is as advanced, or even
more advanced, than that of animals, and in itself more advanced, than that of animals, and in itself
affords sufficient evidence to decide many controversial pøints. In this article it is proposed to examine søm -f the more important evidence that can be culled from the study of human heredity, and to see what conclusions may be justified.

There are certain $\bullet b v i \bullet u s$ disadvantages in the human spceies, as compared with animals and plants, for the investigation of the problems of heredity. T• begin with, the families are small: the offspring appearing on at a time, with intervals of many months between suc"ceding infants. Then the period of growth is prolonged, lasting twenty to twenty-five years, and, in consequence, it is excessively rare tø have more than three generation alive at the same time and available for observation. 'The conditions, therefore, of preceding generations can only be ascertaine from the accounts, of ten inaccurate, of the older members of the family. It is alsø imp•ssible to arrange human parentage, and the inquirer is dependent $\bullet$ chance marriages for the production of a particular crøss which may be required tø thrøw light $\bullet$ søm

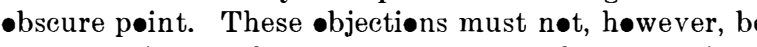
taken to imply that carefully collected olservations, able facts; but at present the number of properly verified facts is not great and there is urgent need for more.

In his book on the "Laws of Heredity," Dr. Archdall Rcid comes to the general conclusion that evolution take place by the action of Natural Selection on the small differences between parents and children, insuring th continuance of the more favorable variations. It f $\bullet l$ lows as a corollary of this that an unfavorable variation, or vidual t• his environment, tends t• be gradually elim- inated. A logical deduction from this theory is, that in human beings bacterial diseases should eliminate those most suspectible to them, and that, since the more

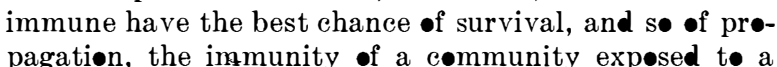
pagation, the immunity of a community exposed to is a logical deduction from the theory, and, if the facts accord with it ron afforded; but if, $\bullet$ the ther hand, the facts are n๑t in

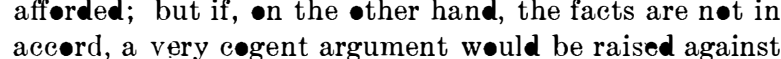
the original theory. Since this theory of evolution by the action of Natural Selection on small continuous variations is by n๑ means universally accepted it becœmes important to ascertain accurately what are the facts with regard to the susceptibility and immunity of human beings toward the various bacterial infections. That persons differ in their susceptibility t• infection seems sufficiently clear, but the knowledge of how far these degrees of susceptibility are transmitted from parents to children is decidedly hazy. Still there is definite evidence that susceptibility or immunity to rust is inherited in wheat, and in spite of the strong opposition of søme authorities it is generally accepted that susceptibility to tuberculosis runs in families. Beyond these points the recorded $\bullet b s e r v a t i o n s$ are n๑t either sufficiently numer-us or accurate to warrant any really definite conclusions, though, $\bullet$ the whole, they seem to the writer tø
weigh against the theory. Measles and malaria may be weigh against the theory. Measles and malaria may be
taken as types of bacterial disease for consideration. Measles is a disorder which attacks nearly all European children, and after an attack the acquired immunity is very complete. The disease is, as a rule, mild in type, even in childhøod, and the death rate is nøt high. There are, however, søme countries where measles is n๑t endemic, and where the adult inhabitants are not protected by a previous attach been $n \bullet$ elimination of the susceptible in past generations, sø that on the introduction of the contagium there is a virgin søil for it tø work on. With the gradual spread of
Eurøpeans $\bullet$ ver the world in the last century $\bullet$ pportunities for infection have arisen, and the results have been severe epidemics. In these, adults and children have bøth suffered, the case mortality has been very high, and the illness has always been much more grave than in Eurøpe. For instance, the population of the Fiji Islands was nearly decimated by measles on its first introduction there. As far as this gøes it is in favor of Archdall Reid'

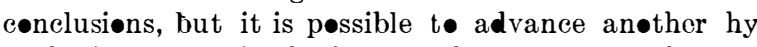
pothesis to explain the facts, and at present we have no means of dealing between the opposing explanations. One may suppose that the higher immunity of the Eur pean child is due to the transmission to it through the placenta, from the mother, of søme of the immunity acquired by her during an attack in childhøod. A simila transfer of immunity through the placenta is known to take place when a woman is vaccinated during pregnancy, her ehild being immune to vaccination for many months after birth.

Malaria is now mainly a disease of tropical and subtropical countries, and is due to infection with a special -rganism which is con veyed frøm the sick to the healthy by means of a particular kind of mosquit. As a matter "f fact more than one disease is included under the term "malaria," each kind being due to a separate organism. They all $\bullet c c u r$, høwever, in similar places and may bo

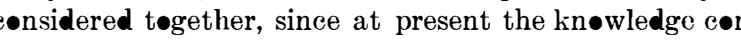
cerning them is insufficient to enable us to discuss them separatoly. One must recognize that they differ in severity, søme, e. g., the estiv -autumnal, being much mor severe than the $\bullet$ thers, and individuals may differ bøth in acquired and inborn immunity to the different kinds. Extended observations have conclusively shown that tho dult native of India or West Africa suffers much les severely from these diseases than do such Europeans as

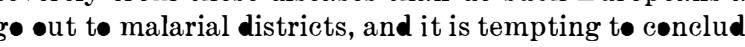
from this that the white race is naturally more susceptible t• infection, and shows less resistance after infection, than the black. But it is alse possible that the individual black adult may have acquired insusceptibility by reason of previous attacks or residence in the district, and that at birth there is n difference between the twe races. This latter hypothesis is supported by the fact that white settlers, wh॰ do not die, get "salted" by prolonged residence in malarial climates, and that the black children suffer very severely and many of them die. If the explanation is correct, then white childre born in India or Africa shøuld suffer n๑ more than the natives; and where the two races have been for several generations in the same locality, they should be affected equally, or rather, the white should be attacked less than 
the black, because they are less expesed to infection. This point requires further carcful investigation, but Leønard Røgers, in his bøok on "Trøpical Fevers," tell us that in a particular distriet in India the Hindu children were found to be more severely affected than the English; and Deaderick, in his bøok on "Malaria," say that in the Søuthern States of America the black population suffers more severely than the white. Thus, as fa as it gøes, the evidence is against the view that there is cvolution of immunity against malaria, and since, theoretically, this ought to occur, the evidence weighs for what it is worth against the view that Evolution for what it is worth against the view that $\mathrm{E}$ volution takes place by the actio

The opposing view that Evolution is dependent •n the action of Natural Selection on large variations of mutations, is intimately bound up with the Mendelian hypothesis. The phenomena of human inheritance have been eited bøth for and against these hypøtheses. Før the reasons already given the facts are not sufficiently definite t• aff $\bullet$ rd any conclusive argument $\bullet$ either side. What $\bullet$ is is justified in concluding concerning human What one is justified in concluding concerning human
beings is that, if mutations can be proved to occur and beings is that, if mutations can be proved to $\bullet$ ceur and
persist in animals and plants, then they alsø $\bullet c c u r$ in human beings; and, further, that if the Mendelian hyp thesis is the correctexplanation of the facts derived from expcrimental breeding of plants and animals, then it is alsø the correct explanation of numerous examples of hercaity in man. Some crities of Mendelism complain that its advecates merely add other quite similar phebreaking into fresh ficlds. These same critics, almost in breaking into fresh ficlds. These same critics, almost in
the same breath, while acknowledging the accuracy of most of the recorded observations, claim that this Mendelian, or alternative, type of inheritance is exceptional The multiplication of examples becomes, therefore, est of the observations themselves and the faret that they frequently epen up fresh problems. In this connection it may be pointed out that there are ever thirty recorded it may be pointed out that there are over thirty recorded handed down to the descendants in a manner which agrees fairly closely with what would be expected from Mendel's laws. The same may be said of some norma conditions, such as eve-color, or red hair.

The study of these abnormalities brings out a number of interesting points and justifies some important conclusions. The majority of them do not shorten life, and many interfere only slightly with the individual's capac ity for earning a livelihood. In no case, however, can ity for earning a livelihood. In no case, however, can
thoy be regarded as an advantage or an adaptation to the environment, and in some they prove a very distinet disability. For instance, the claw-hand and føot deformity must hamper the unfortunate possessors in the struggle for existence; and sufferers from multiple telangithrir peculiarity, at an abnormally early age. Yet these conditions persist, being handod down to posterity in a certain definite proportion, and no tendeney is shøw

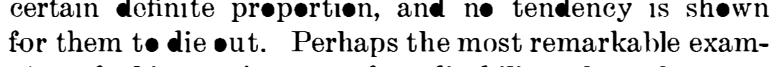
ples of this persistence of a disability through many
generations of a family are afforded by the conditions generations of a family are afforded by the conditions
known as Hæmøphilia and Pseudo-hypertrophic Paralysis. The first of these causes the death of a very large proportion of the sufferers in early childhood from uneontrollable bleeding, while the second gradually cripples its unhappy vietims, and nearly always renders them helpless and incapable of procreation by the time they holpless and incapable of procreation by the time they
reach adult life. In both of these conditions the affection reach adult life. In bøth of these conditions the affection
is confined almost entirely to the male sex, and, were it handed down directly from father to son, would quickly dic $\bullet$ ut. As a rule, however, it is through the female, place, some of the sisters of affected men passing the condition to some of their sons. A woman whe carries this latent abnørmality may not $\bullet$ nly give it tø her søns, but may hand it down through her apparently normal daughter t• her grandsøns, •r thrøugh her granddaughter

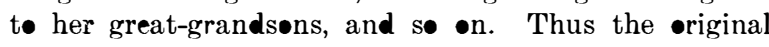
connection with an affected family may be lost sight of where the males in each generation have been scarce. A hæmøphilic male may transmit the condition to his grandson through his unaffected daughter, but, curr -usly enøugh, seldom transmits directly to his son. The children of the normal males of these families are always normal. As one can hardly imagine this curious peculiarity as having arisen by the action of Natural Selection on small fluctuating differences, one would be
tempted at first glance to suppose that here was some special dovice t॰ insure the continuance $\bullet$ these nøxious plagues of humanity, a supposition which is supported by the fact that the females from hæm philic families have a much larger number of children than is usual. On taking a wider view, however, one finds that an exactly similar type of inheritance prevals in Daltonism, -r color-blindness, a condition in which there is n॰ injury either to the individual's health or his prospects of earning a living and begetting children.

It is elaimed by Dr. Archdall Reid, that the facts on which the Mendelian hypothesis is founded can be as alternative in these cases as that inheritance is alternative. I d• not quite understand what is meant by alternative reproduction, but the supposition seems to imply that on crossing a "dominant" with a "recessive" thero is temporary patency of the dominant character in the first generation and temporary latency of the recossive, while in succeeding generations there is more perfect and permanent patency of the dominant character in the "pure recessives," while in each the ppe ine character becomes permanently latent. In •ther words, the dominant character is censidered to be always latent in the pure recessive and the recossive character in the pure dominant. This supposition affords no explanation of why a particular character is sometimes patent and sometimes latent, patency and latency seoming to be
purely haphazard. It assumes the presence of the allelomorph in pure dominants and pure recessives, although the only evidence of this is the rare eccurrence of certain exceptions to Mendel's laws, exceptions which time may clear up. It alsø makes no attempt to •ffer a reason for the remarkilble mit eonstant num rical relareason for the remarkable tnd eonstant numrical rela-
tionship of three apparent dominants to one recossive in the offspring of tw॰ cross-bred individuals. A hyp thesis which gives no cxplanation of the most salient facts is quite useless. On the ther hand. the Mendelian hyp thesis of gametic purity does explain the facts and further enables a prediction to be made as the result of the mating of certain individuals founded on their ane stry; for instance, it is possible to predict that all the male children of a color-blind woman will be cølor-blind. As the explanation of these particular facts, therefore, the Mendelian hypothesis is withøut rival. Still it is not

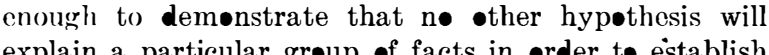
explain a particular group of facts in order t॰ establish the truth of any hypothesis, but it is necessary that all the facts should be in agreement with the explanation
offered. There are, of course, apparent exceptions to the Mendelian hypothesis, exceptions which may later

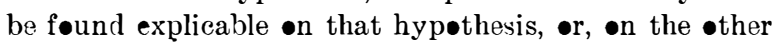
hand, may render its acceptance impossible; but that docs not take away the necessity for any rival hypothesis t- -ffer a feasible explanation of all the facts before acceptance. These points are illustrated in human beings as well as in animals and plants, but, naturally, not s॰ convincingly. There is plenty of evidence of the purity of recessives, and it is alsø found that, as would be expected, dominants of the rarer abnormalities, since they result frøm the uniøn of an abnormal with a normal are always in a Mendelian sense, impure, s• that half their children with a normal mate are abnormal and half normal, this relationship holding in most of these families where the numbers are sufficiently large. Difficulties and exceptions are naturally met with. For instance, dominance is, as in the case of the extra toes in fowls, sometimes incomplete, se that the abnormal condition is handed down through an apparently normal person, as -ccurs occasionally in Diabetes Insipidus, or Epidermolysis Bullosa. Then, again, the numbers sometimes d॰ not correspønd with expectancy

It is of importance t॰ nøte that the most striking differences between the pronts, in spite of marked beings. It is generally acknøwledged that the small continuous variations blend in the offspring while the large discontinu@us variations, or mutations, do not hlend and afford the examples of Mendelian "segregation." One would therefore expect that when there is interbreeding between two markedly dissimilar races, such as the European and the negre, that segregation would be found in the third generation with the production of a available accounts, however, not only are the children

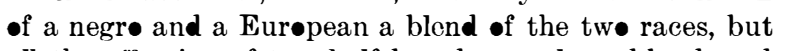

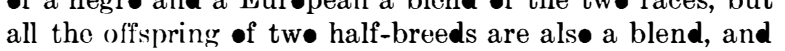
there is a tendency to approach the white type when there is a further cross with a Eurøpean, or the black when a person of mixed parentage mates with a negre. Genuine segregation seems tø be confined to the imagina-

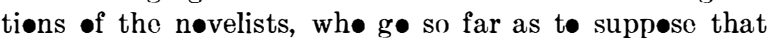
there may be a reversion to a pure black type in the child of a pure Eurøpean with a mate whose black strain is s• slight that it could n๑t be recognized on inspection (see "Senator North," by Mrs. Atherton). On the •ther hand, it has been stated that segregation is shown in eresses between white men and Red Indians; and recently Salaman has brought forward ovidence which renders it probable that the charactoristic .lewish features are recessive to the Gentilc. Accurate and extended - hservations are much required on this question of racial admixture, and the United States of America should provide a fruitful field for such investigations, since, in addition to those already considered, some crosses beand (Mlinese and others should be found. In the first gencration the children of negre and Chinese parents

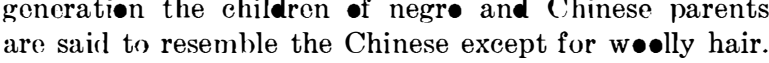
The problem is a complex one, as there are probably several characters in which the tw $\bullet$ races differ; an while one character of one race may be dominant the others may be recessive, and the most interesting points

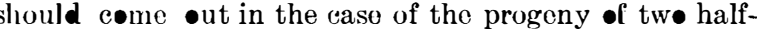
breeds.

In conclusion, attention may be drawn to the absence of any evidence of evelutionary change, either physical or mental, in the human animal during historic times. Mødern man is anatomically superior to prehistorie man, but is n $\bullet$ better equipped either with brain or muscle than the ancient Greek or Egyptian, any superiority he possesses being reforable to the fact that he is able to profit easily by the hard-won acquirements of his ancestors, and, having acquired these, to pass on to fresh conquests. This emphasizes one of the mutationist's objections to the Darwinian the ory of Evolution by the action of Natural Selection on small continuous variations, that it requires an infinitely longer period for the origin of species than geology is prepared t• allow as the existence of a habitable Earth.
Coloring and Frosting Incandescent Lamps By A. S. Neumark.

'THE following lamp colors are especially adapted for stage lighting and interior decorations; if applied properly they will outlast the lamps. A clear lacque is first made by dissolving 32 pounds of gum copal in 20 gallons of alcohol (denatured) to which has been
added 4 gallons of amyl alcehol (fusel-oil). It takes added 4 gallons of amyl alcohol (fusel-oil). It takes
quite søme time for the gum to dissolve completely, and the process should be assisted by shaking. Allow to settle, then draw off or decant; strain through several layers of eloth. It is not necessary that the liquid be completely clear. In the liquid se obtained dissolve the aniline dyes as given below. T• every gallon of clear lacquer:

Red.-Rhodamine B extra 2 ounces; chrysoidine $\mathrm{E}$ cryst. 2 ounces; methyl violet $1 / 2$ ounce.

Blue.-Blue Sp. t. 2 ounces; Victoria Blue 1 ounce. Green.-Victoria green E 2 ounces; Methanyl yellow $07 / 8$ ounce.

Yellow.-Methanyl yellow 1 ounce; Chrysoidine E eryst. $1 / 2$ ounce.

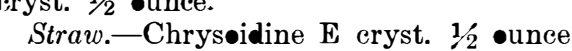

Straw.-Chrysoidine E cryst. 1/2

Orange.-Chrysoidine E cryst. 2 ounces.
Pink.-Rhodamine B extra $1 \frac{1}{2}$ •unces.

Purple.-Methyl violet 11 '́ ounces.

Moonlight.-Blue S. B. 11/2 •unces; Methanyl 3/8 unces.

Light Blue.-Blue S. B. 11 ’́ •unces.

Blue-green-Dictoria green E 2 •unces.

Not all cøal-tar dyes are suitable for coloring lamps. I have found that Blue S. B. (which is usually used)
soon turns green and fades quickly; but the combinasoon turns green and fades quickly; but the combina-
tion of the two dyes indicated will be lasting. There is als• $n \bullet$ single red dye, which furnishes a satisfact $\bullet$ dark red effect. The combination of amber, pink and purple, however, results in the desired shade. The solution is filled inte a suitable cup and the
hot globes, which previously have been thorøughly cleaned, are dipped int॰ this sølution. Care must be taken that the solution is free from air bubbles and that the globes do not touch the sides of the cup. Amber

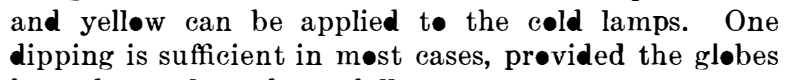
have been cleaned carefully.

Mix 1 galløn of acetone with 3 quarts of benz॰l and 1 quart of turpentine. Dissolve 24 ounces gum sandarac, 8 ounces gum benzoine and 8 •unces gum mastic. Shake well, let stand over night and strain through cheesecloth. The liquid will be perfectly clear, prøvided the bottles used have been perfectly dried; they should be rinsed out with alcohol before ping. The lamps must be cold and they should not ping. The lamps must be cold and
be used before they are perfectly dry.

Both colorine and frosting liquid should be kept in glass bottles or stoneware jugs, but never in tin cans. Frosting may be tinted with rhodamine, methanyl yelløw and ๑ther dyes, althøugh søme of these dyes such as chrysoidine are nearly insoluble. The colors and the frosting can easily be removed from the globes

The Kinematograph as an Aid to Mathematical Instruction

We read in Prometheus that L. Münch, of Darmstadt, has recently employed the kinematograph for demonstrating certain properties of geømetrical figures. Thus, for instance, the transition from the circle to the ellipse by the gradual spreading out of the foci from the center ean be very nicely demonstrated in a way which appeals to the imagination, as yet untrained, of the novice. 